\title{
The impact of modifications of the smectite-bearing raw materials on their thermal expansion ability
}

\author{
Wojciech Panna $^{1} \cdot$ Magdalena Szumera $^{1} \cdot$ Piotr Wyszomirski $^{1,2}$
}

Received: 19 June 2015/Accepted: 31 August 2015/Published online: 14 September 2015

(C) The Author(s) 2015. This article is published with open access at Springerlink.com

\begin{abstract}
The effects of modifications of the clay rocks containing smectite on their thermal expansion have been studied at the example of the claystones from Dylągówka (Dynów Foothills, south-eastern Poland). Hot-stage microscopy was employed combining a dedicated procedure of digital image analysis. The chemical modification of three rock types from the Dylągówka deposit included the treating with an addition of $\mathrm{Na}_{2} \mathrm{CO}_{3}$, activation with a $\mathrm{H}_{2} \mathrm{SO}_{4}$ solution, and firing at $560{ }^{\circ} \mathrm{C}$. X-ray diffraction and thermal analyses (DTA, TG) helped determine the impact of the modification processes on the structural changes in smectite, the major component of the rocks in question. The investigations into thermal expansion have shown that the clay rock varieties poor in $\mathrm{CaO}$ can be acid-activated with a significant improvement their expansion in comparison with such an ability of natural rock equivalents. It is a result of introducing silica into the melt that forms on heating the natural clay rock at high temperatures due to its presence of alkalis $\left(\mathrm{Na}_{2} \mathrm{O}\right.$ and $\left.\mathrm{K}_{2} \mathrm{O}\right)$. The silica, in turn, comes from the protonated silica gel generated due to the acid treatment of smectite-bearing rocks. The liquid phase (the melt) with a high viscosity may form a cover on the surface of granules of the product being fired and prevents the expulsion of gases into the ambience. An addition of $\mathrm{Na}_{2} \mathrm{CO}_{3}$ is favourable as it considerably lowers the firing temperature of the expanded product, both in the case of clay raw materials poor and rich in $\mathrm{CaO}$. The acid
\end{abstract}

Wojciech Panna

wojpan@agh.edu.pl

1 AGH University of Science and Technology, Mickiewicza 30, 30-059 Cracow, Poland

2 State Higher Vocational School, Mickiewicza 8, 30-100 Tarnów, Poland activation of the latter variety ( $\mathrm{CaO}$-rich) is less effective because of the reaction of acid $\left(\mathrm{H}_{2} \mathrm{SO}_{4}\right.$ used by the authors) with calcite; the mineral is decomposed, and at least part of the acid does not activate a clay material.

Keywords Thermal expansion $\cdot$ Smectites $\cdot$ Hot-stage microscopy $\cdot$ Acid activation · Clays

\section{Introduction}

Smectites are considerably fine-grained alumino-silicate minerals, characterized - among others—by a high cation exchangeability, a property of swelling in water or when exposed to humid air, a high specific surface, good sorption properties, and also by other features resulting from their layer structure $[1,2]$. These minerals are widespread in the nature, with the prevalence of the Ca-smectites, which show much worse sorption properties than the Na-smectites because of a stronger interlayer interaction with bivalent cations. These properties can be improved by exchanging their interlayer cations.

Sodium activation, the most often used industrial and laboratory procedures, is based on treating a wet, ordinary clay starting material with a certain amount (to $5 \%$ ) of sodium carbonate $\mathrm{Na}_{2} \mathrm{CO}_{3}$, which produces an Na-smectite with a much higher specific surface than that of its predecessor (containing mainly $\mathrm{Ca}^{2+}$ cations in interlayer sites) and with a high sorption ability.

Another commonly used laboratory and industrial method of activating bentonites is their acid treatment. The commercial, acid-activated bentonites are called bleaching earths and used in the food and paper industries [3]. The acid activation of smectites is based usually on inorganic acids $\left(\mathrm{HCl}, \mathrm{H}_{2} \mathrm{SO}_{4}\right)$ with various concentrations $[4,5]$. The 
process is conducted at elevated temperatures (to about $80{ }^{\circ} \mathrm{C}$ ) and a time determined by a desired degree of processing the starting smectite-rich material. The quickest part of the process involves removing the exchangeable cations and their replacing in the clay structure by protons. The next stage involves the acid treatment resulting in removing central cations (such as $\mathrm{Al}$ and $\mathrm{Mg}$ ) from the octahedral sheet, which considerably affects a resultant clay mineral charge. The process provides either a final product in the form of the $\mathrm{H}$-smectite with protons at the interlayer positions or, in the case of more aggressive acid treatment, a protonated silica gel characterized by a much more evolved specific surface than that of a starting clay material [6].

The type of the exchangeable cations and the resultant charge of the layer considerably affect the process of thermal treatment of smectites. Investigations into dehydration of smectite-containing clay rocks at temperatures below $400{ }^{\circ} \mathrm{C}$ are not so simple because of the coincidence of the thermal effects caused by removing the interlayer water and the water coordinated by exchangeable cations [7]. At a temperature of about $500{ }^{\circ} \mathrm{C}$, the process of dehydroxylation begins, which for the Na-smectites reaches a maximum at a temperature of about $700{ }^{\circ} \mathrm{C}$. The corresponding mass decrease (due to a loss of the $\mathrm{OH}$ groups) in the Na-smectite is $3.5 \%$ on the average but is lower in other smectite varieties, following the rule that the higher the layer charge the lower mass loss is [8]. A small cation radius of monovalent ions favours their migration into the tetrahedral sheet at lower temperatures, which results in shifting the dehydration effect in thermal curves towards lower temperatures [9]. In consequence, another endothermic effect appears in the DTA curves at $800{ }^{\circ} \mathrm{C}$, whose presence is associated with a final breakdown of the smectite structure. It is usually accompanied by an exothermic effect at slightly higher temperatures, caused by the formation of new silicate phases, such as quartz, cristobalite, mullite, and anorthite, depending on the chemical composition of the smectite analysed and, thus, available products of its breakdown [10].

Industrial thermal processing of smectite-bearing clay rocks is conducted to obtain materials used, among others, in the building industry. At the temperatures $800-1000{ }^{\circ} \mathrm{C}$, an attractive cement additive is produced, a material with an elevated pozzolana activity [11]. Another product is represented by lightweight expanded clay aggregate (LECA) obtainable at temperatures exceeding $1100{ }^{\circ} \mathrm{C}$. It is produced of clay raw materials - often with the smectite properties - that on heating reveal an even fivefold increase in their volume due to, among others, evolving gases [12]. The product has a form of pellets with hard, sintered surfaces, while their porous interior shows a mechanical strength and can be used in a building practice as thermal and acoustic lightweight aggregates, as components of lightweight concretes and concrete prefabricated products, but also in horticulture and geotechnics [13].

Thermal expansion occurs when mineral phases present in clay rocks reach on heating the pyroplastic state, while a pressure of evolving gases is high enough to increase the volume of the closed [14]. These processes take place after exceeding the range of firing of the clay rock, i.e. at temperatures above $1100{ }^{\circ} \mathrm{C}$. Under such conditions, some clays become softer and expand, which is manifested by a quick increase in their volume and porosity. The gases evolving on heating depend on the mineral composition of the clay rock and can result from decomposition of clay minerals, decomposition of minor mineral components such as carbonates (calcite) and sulphates (gypsum), and also from high-temperature redox reactions. The list includes $\mathrm{CO}_{2}, \mathrm{SO}_{2}$, and $\mathrm{O}_{2}$ (the latter derived in reduction of iron oxides) [15]. The expansion ability can be adjusted in a technological process by introducing additives, for example, waste materials from refineries and fat-producing plants, coal mud, and even communal sludge [16]. Various possibilities of utilization of the smectite materials gave rise to initiate further studies on the bentonite claystones from the deposit in Dylągówka (Dynów Foothills, southeastern Poland). In comparison with previous investigations into such mineral raw materials [13, 14], the present authors have considered the possibilities of controlling the thermal expansion of smectite-bearing clay rocks by their chemical modification. The investigations focused on the expansion of the bentonite claystones from Dylagówka were carried out with a hot-stage microscope Misura HSM $3 \mathrm{M}$ and were supported applying a new, dedicated digital image analysis proposed and described in details by Panna et al. [16].

\section{Sample material}

The investigations were carried out on samples of the bentonite clays from Dylągówka (south-eastern Poland, Podkarpackie Voivodeship) characterized in detail by two of the present authors [17]. Three samples were collected from various depths of the deposit. The rocks contain considerable amounts of clay minerals, i.e. smectite, illite, and kaolinite. The contribution to the first of them in a natural rock usually exceeds $30 \%$. The first variety (sample A) from the highest horizon of the Dylągówka deposits and represents Lower Eocenian, brick-red brownish clinoptilolite-montmorillonite claystones, whose occurrences have also been found in other areas of the Dynów Foothills. The remaining rocks from the lower horizons of the deposit are brownish and light green (samples B and C, respectively) and can be classified as 
siliceous-montmorillonite claystones because of their elevated opal contents [17].

The samples were dried and milled in a laboratory ball mill. Next, three starting samples $\mathrm{A}, \mathrm{B}$, and $\mathrm{C}$ were sodium-modified: each of them was spiked with $\mathrm{Na}_{2} \mathrm{CO}_{3}$ in an amount of $5 \%$ of the rock dry mass, physically activated using a mechanical mixer, followed by 30-day homogenizing, next drying the products, and renewed milling. Such samples activated with $\mathrm{Na}_{2} \mathrm{CO}_{3}$ were designated as A1, B1, and C1. Another three starting samples were acid-activated: after powdering $100 \mathrm{~g}$ of each of them, the material was treated with $100 \mathrm{~mL}$ of the $10 \%$ $\mathrm{H}_{2} \mathrm{SO}_{4}$ solution, followed by a 30 -min homogenizing using a mechanical mixer, 24-h ageing in a climatic chamber at $80{ }^{\circ} \mathrm{C}$ and the relative humidity $H_{\mathrm{r}}=90 \%$, and then by drying and ball milling. The samples of this series were designated as A2, B2, and $\mathrm{C} 2$. Thermal activation at $560{ }^{\circ} \mathrm{C}$ was carried out only on the material from the upper horizon of the deposit, represented by a raw sample and the sample modified with $\mathrm{Na}_{2} \mathrm{CO}_{3}$. The thermally activated samples were designated as $\mathrm{A} 3$ and $\mathrm{A} 4$.

\section{Methods of investigations}

XRD analysis was used as a standard method of establishing the mineral composition of the clay rocks. An X'Pert Pro (Philips) was the X-ray diffractometer (the filtered $\mathrm{Cu}_{\mathrm{K} \alpha}$ radiation, recording speed $10 \% \mathrm{~min}$.), which worked online with a HighScore Plus software and an ICSD database in the mineral phase identification.

Thermal analyses were conducted using a STA7 Jupiter (Netzsch) to record the thermogravimetric (TG) and thermal differential (DTA) curves of air-dry, ground samples. The analytical conditions were as follows: air atmosphere; heating rate $10 \mathrm{~K} \mathrm{~min}^{-1}$; sample mass $100 \mathrm{mg}$; and temperature range (RT) $1200{ }^{\circ} \mathrm{C}$. The method was supplemented in the case of one sample (A2) with an analysis of evolving gases (EGA), carried out with a STA449F3 analyser (Netzsch) combined with a QMS gas analyser.

The course of thermal expanding of natural and modified clay raw materials was traced applying hot-stage microscopy (HSM). Using a HSM microscope, it was possible to determine the temperatures corresponding to characteristic changes in the shape and the surface area of the samples observed continuously in their transversal cross sections. The images were used to observe whether the sample material expands on heating and, if it does, to record the temperatures of its characteristic changes, i.e. of firing, softening, expanding, melting, and flowing. These data form the basis to establish the temperature ranges of the firing process of the expanded product [16].
Considering the difficulties in a precise recording of specific technological temperatures and determining the expansion coefficient $S$, the authors used the method of determining the progress of thermal expansion with the MATLAB software, version 2013b. It facilitates a continuous measuring of the surface area of the geometrical figure being a transversal cross section of the sample being heated. The proper procedure of image analysis [16] measures and records the thermal changes in the sample cross section in relation to the cross section of the starting sample in the function of temperature.

The samples for the HSM were made with a hand press from a disintegrated $(<0.25 \mathrm{~mm})$ material as tablets with a diameter of ca $2 \mathrm{~mm}$ and a height of ca $4 \mathrm{~mm}$. The measurements were taken using a hot-stage microscope Misura HSM $3 \mathrm{M}$ (Italy) at the heating rate $10 \mathrm{~K} \mathrm{~min}^{-1}$.

\section{Results and their discussion}

\section{X-ray investigations into natural and modified samples}

The XRD analyses (Fig. 1) reveal that all the natural samples (A, B, and C) contain such major silicate phases as smectite, quartz, and opal. More diversified in its mineral composition is sample A from the upper horizon of the deposit, the only one in which also zeolites (clinoptilolite) occur at a significant amount at the expense of opal and smectite. These phases are accompanied by illite, kaolinite, and finely dispersed haematite. The latter gives the characteristic red colouration of the rocks from this horizon. Going deeper into the deposit profile (samples B and C), the rocks have a much simpler composition being of a smectite-siliceous character. The X-ray patterns of both samples show an elevated background in the angular range $\approx 18-24^{\circ} 2 \Theta_{\mathrm{CuK} \alpha}$, which is indicative of a noncrystalline matter, in this case of opal. Further mineral differences in the vertical profile in Dylągówka are shown, among others, by variable ratios among the clay minerals. Kaolinite co-occurs with smectite in the lower part of the deposit (sample C), while minor illite amounts are present in the middle part of the deposit (sample B). In addition, the reflections of a carbonate mineral-calcite-were recorded in the X-ray patterns of sample $\mathrm{C}$.

Technologically oriented modifications, carried out on the natural samples from the three horizons distinguished, show the structural changes in smectite, visible in the X-ray patterns of samples A1, A2, A3, and A4. The sodium activation shifts the first, low-angle 001 reflection of smectite with the $d_{001}$ value about $14 \AA$ (sample $A$ ) to $12.5 \AA$ (sample A1). The reflection shifted is also 


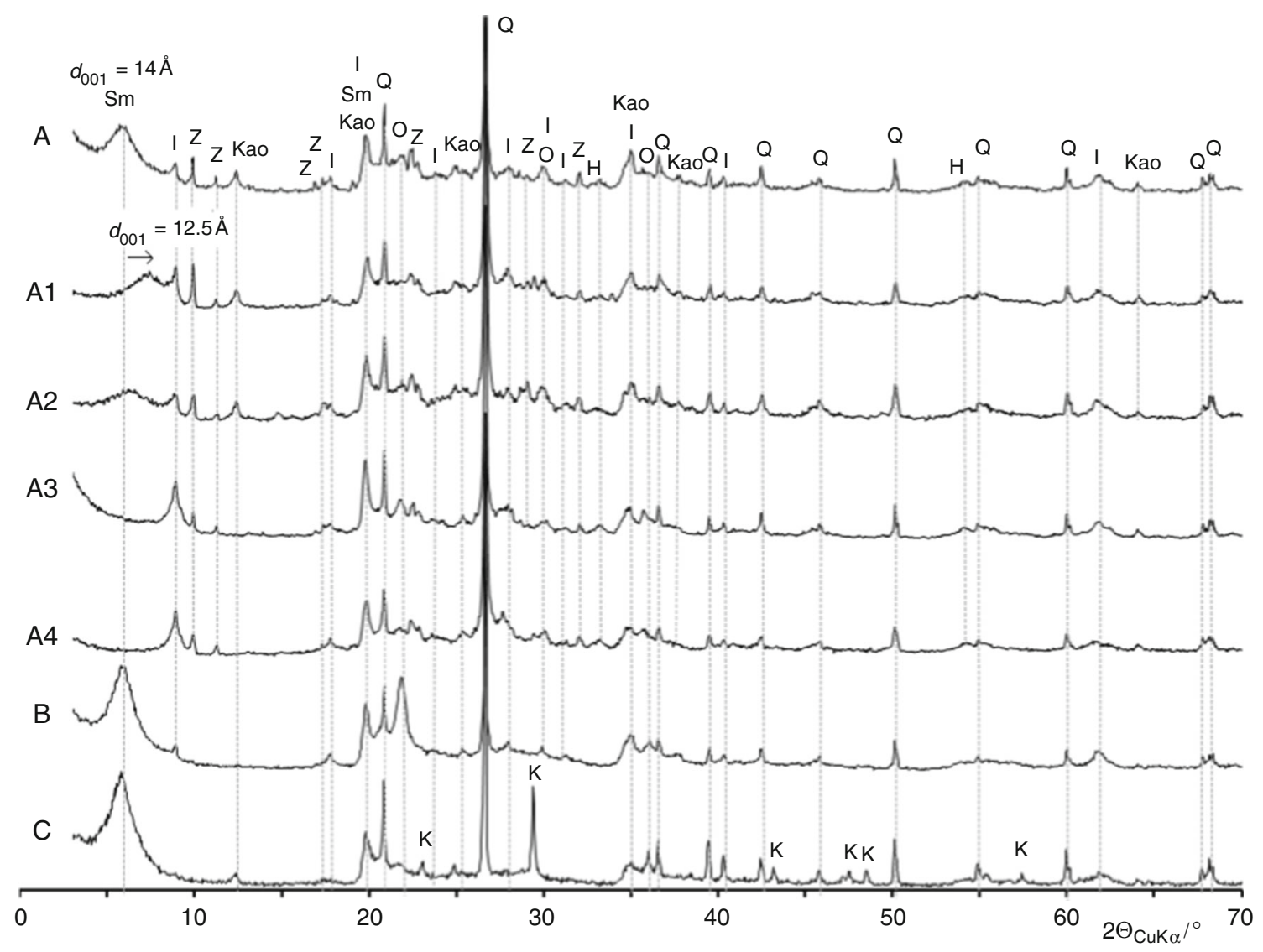

Fig. 1 X-ray patterns of the natural claystones from the upper $(A)$, middle $(B)$, and lower $(C)$ horizons of the Dylągówka deposit and of the products of the modified A series samples: $A 1$ - sample activated with $5 \%$ (by mass) of $\mathrm{Na}_{2} \mathrm{CO}_{3}, A 2$-sample activated with $10 \%$

significantly broader in comparison with the basal reflection of the natural sample. The broadening is associated with a breaking down larger aggregates of the Ca-smectite occurring in the natural sample, due to calcium replacement by $\mathrm{Na}^{+}$ions in the interlayer spaces of the Na-activated smectite. Another modification, i.e. acid activation, results in lowering the intensity of the smectite basal reflection (001) and elevating in the angular range $\approx 18-30^{\circ} 2 \Theta_{\mathrm{CuK} \alpha}$ the X-ray pattern background of sample A2. These are proofs of a structural damage in a substantial part of smectite and its transition into a protonated silica gel; the same observations made, among others, Pentrák et al. [6]. Thermal activation of natural (A3) and sodium-modified (A4) samples leads to a total collapse of the smectite structure [9]. It can be deduced from a disappearance of the most intensive, basal reflection of this mineral, which is present at low angles with $d_{001}=12.5-14 \AA$. solution of $\mathrm{H}_{2} \mathrm{SO}_{4}, A 3$-sample fired at $560{ }^{\circ} \mathrm{C}, A 4$-sample activated with $5 \%$ (by mass) of $\mathrm{Na}_{2} \mathrm{CO}_{3}$ and fired at $560{ }^{\circ} \mathrm{C}$. Explanation of symbols: $H$ haematite, $I$ illite, $K$ calcite, $K a o$ kaolinite, $O$ opal-CT or opal-C, $Q$ quartz, Sm smectite, $Z$ zeolite (clinoptilolite)

\section{Thermal analysis}

The curves of thermal analysis of sample A (Fig. 2) indicate that the most useful in interpretation is the first derivative thermogravimetric curve, i.e. the DTG curve. It shows best the changes in the range from the ambient temperature to $900{ }^{\circ} \mathrm{C}$ due to modifications of the samples described above. The loss of mass in sample A proceeds in many stages. In the range $100-250{ }^{\circ} \mathrm{C}$, clay minerals undergo dehydration: the mass loss is about $6.3 \%$, resulting mainly from a substantial amount of smectite. The inflection on the DTG curve at around $160{ }^{\circ} \mathrm{C}$ indicates that the dehydration process of the $\mathrm{Ca}$-smectite is gradual, because its exchangeable cations coordinate in the smectite structure several layers of water molecules (Fig. 2a) [8]. The exothermic effect in the DTA curve (Fig. 2b; also appearing in the DTG curve) with a maximum at around $345{ }^{\circ} \mathrm{C}$ comes probably from a burn-down 


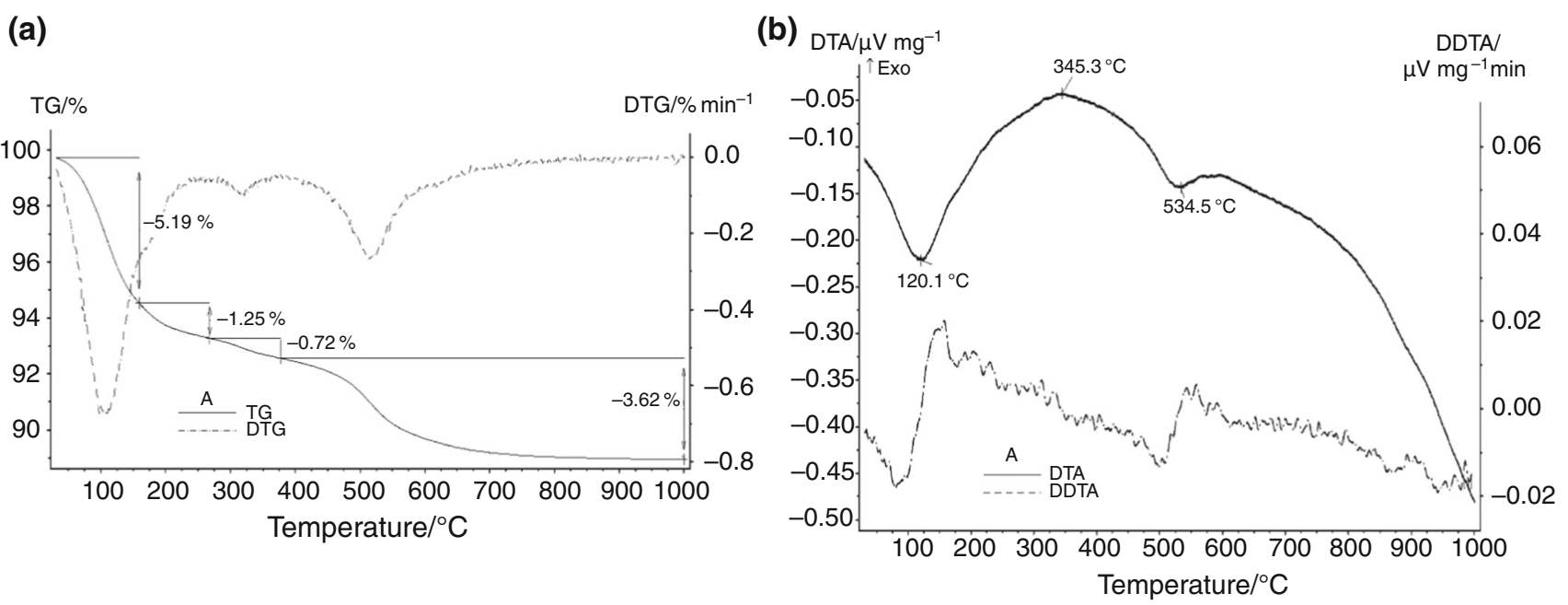

Fig. 2 Curves (a-TG and DTG, b-DTA and DDTA) of the claystone from the upper horizon of the Dylągówka deposit (sample a)

Fig. 3 DTG curves of the claystone from the upper horizon of the Dylągówka deposit: $A$-natural sample, Al-sample activated with $5 \%$ (by mass) of $\mathrm{Na}_{2} \mathrm{CO}_{3}, A 2-$ sample activated with $10 \%$ solution of $\mathrm{H}_{2} \mathrm{SO}_{4}, A 3$ - sample fired at w $560{ }^{\circ} \mathrm{C}, A 4$ - sample activated with $5 \%$ (by mass) of $\mathrm{Na}_{2} \mathrm{CO}_{3}$ and then fired at $560{ }^{\circ} \mathrm{C}$

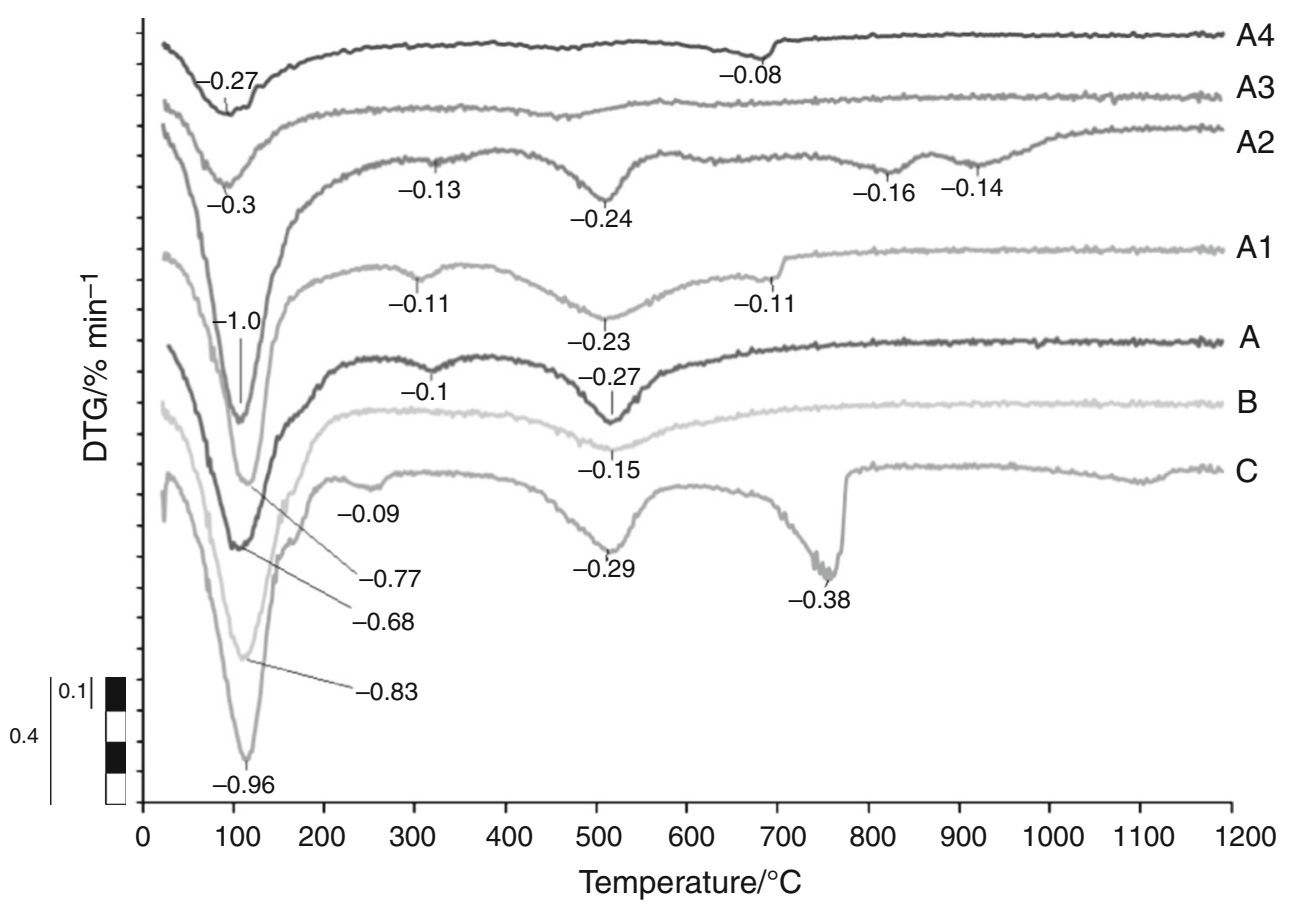

(oxidation) of organic matter and is associated with the mass loss around $0.7 \%$. A similar effect was found in the sample C (Fig. 3), however, due to a higher dispersion of mineral substances than in the sample A-the effect is shifted towards a lower temperature. The thermal effects in the range $400-800{ }^{\circ} \mathrm{C}$ correspond to a small loss of water (around $3.6 \%$ ) and are caused by dehydroxylation of clay minerals. Such a wide temperature range results from a superposition of such effects of kaolinite, smectite, and illite. The maximum at around $534{ }^{\circ} \mathrm{C}$ corresponds with the endothermal effect (recorded in the DTA and DDTA curves) of dehydroxylation of kaolinit and illite (Fig. 2b). Of the three clay minerals mentioned, kaolinite is responsible for the highest loss of mass (if a sample is composed of $100 \%$ of kaolinite, it is ca. $12 \%$ ) caused by evaporation of water molecules formed from the $\mathrm{OH}$ groups [18]. The differences of dehydroxylation values in samples A, B, and C (Fig. 3) are due to various amounts of individual clay minerals, but pronounced thermal effects in samples A and $\mathrm{C}$ are associated mainly with the presence of kaolinite. Other thermal effects, above $900{ }^{\circ} \mathrm{C}$, could not be recorded because of instability of the DTA curve. 
The DTG curves of the modified smectite material are presented in Fig. 3, and the interpretation of thermal effects is described below at the example of the A series samples. Introducing sodium cations into the interlayer spaces of smectite (sample A1) results in a one-stage dehydration, although shorter than in the case of the natural sample (A), corresponding to a mass loss of $5.8 \%$. The process is associated with the fact that the sodium cation coordinates in the smectite structure only a single layer of water molecules. Another endothermal effect is distinct and appears at around $690{ }^{\circ} \mathrm{C}$, indicating that the process of dehydroxylation of the Na-smectite is much faster than that observed in the Ca-smectites. Such a phenomenon is caused by different mechanisms of collapsing the structure of these two smectite varieties on heating. If the smectites contain bivalent cations in their interlayer spaces (sample A), such cations migrate then into the tetrahedral sheet. The migration of the water molecules formed at the expense of the $\mathrm{OH}$ groups present in the octahedral sheet proceeds by diffusion and is slow; therefore, it is not accompanied by a distinct dehydroxylation effect (that around $690^{\circ} \mathrm{C}$ ) on the DTG curve of the natural sample. In turn, as the sodium cations do not migrate into the tetrahedral sheet of the Na- smectite, dehydroxylation of this mineral is more spontaneous, being reflected as a distinct thermal effect [19].

In the case of acid activation (sample A2), dehydration takes place in a wider temperature range, from 40 to $250{ }^{\circ} \mathrm{C}$, and the accompanied mass loss is higher, around $8.9 \%$, in comparison with the sodium-activated sample. The explanation is that the $\mathrm{H}$-smectite contains significantly more water in its interlayer spaces. The major effect of dehydroxylation of the $\mathrm{H}$-smectite takes place at around $620-680{ }^{\circ} \mathrm{C}$ and is relatively diffused. This process covers a lower temperature range than that of the Na-smectites (680-720 $\left.{ }^{\circ} \mathrm{C}\right)$ [20]. Further effects, at the temperatures $740-860$ and $880-980{ }^{\circ} \mathrm{C}$, are attributed to the emission of sulphur(IV) oxide, which was detected in the EGA analysis (Fig. 4). The emission of $\mathrm{SO}_{2}$ is a result of decomposition of the sulphates, such as $\mathrm{MgSO}_{4}$ and $\mathrm{CaSO}_{4}$, formed by acid activation $\left(\mathrm{H}_{2} \mathrm{SO}_{4}\right.$ was used).

Thermal analyses of the natural (starting) sample fired at $560{ }^{\circ} \mathrm{C}$ (A3) and its sodium modification (A4) (Fig. 3; DTG curves) show in both cases much lower dehydration mass losses (around $3.3 \%$ by mass). There are no dehydroxylation effects that could be linked to kaolinite and illite because the $\mathrm{OH}$ groups of these minerals were
Fig. 4 Evolved gas analysis EGA of the acid-activated claystone from the upper horizon of the Dylągówka deposit (sample A2)

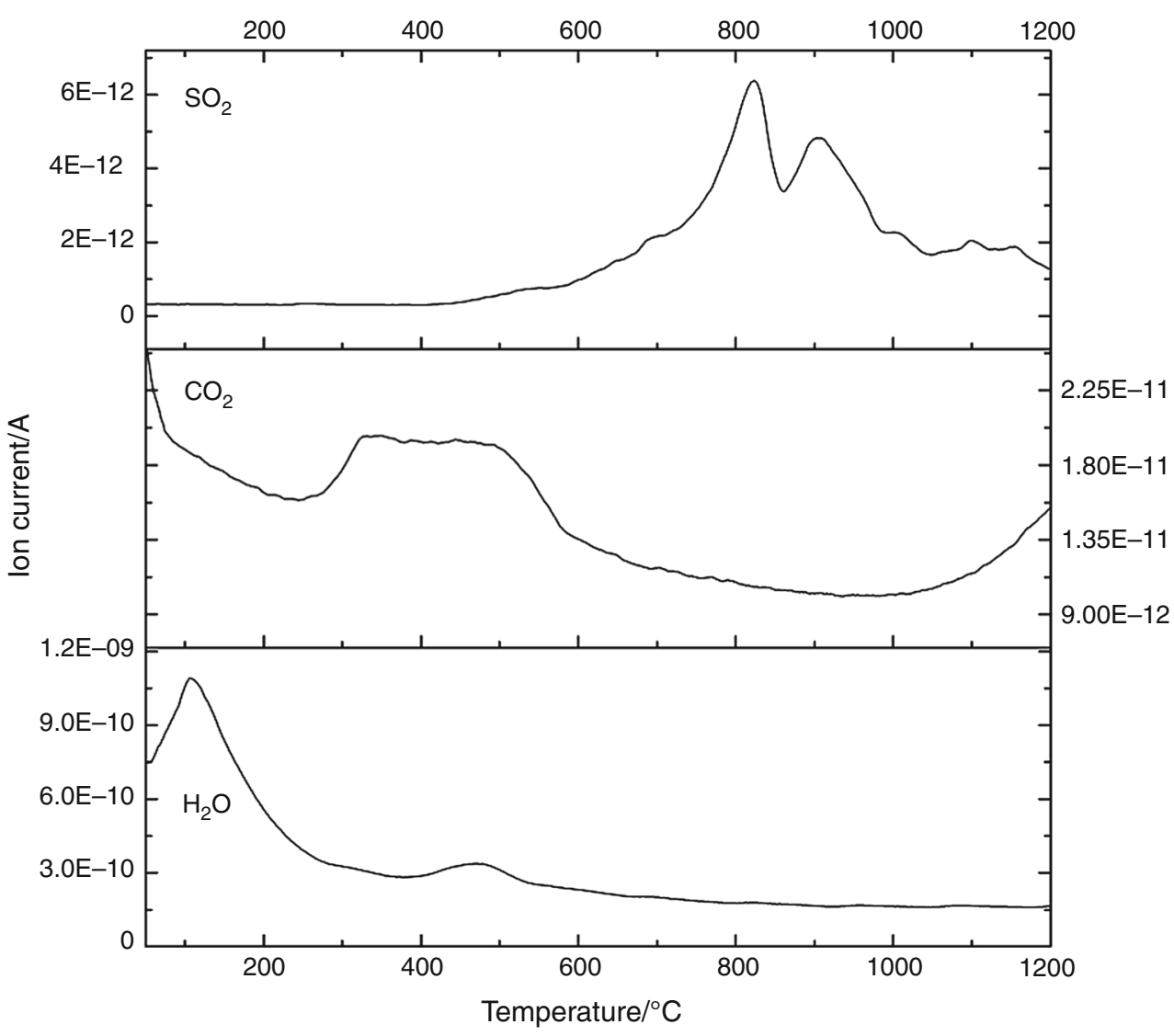


removed during firing. Only in the sample A4 (Na-activated, then fired at $560{ }^{\circ} \mathrm{C}$ ) the effect of dehydroxylation of smectite was observed at around $690{ }^{\circ} \mathrm{C}$.

\section{Hot-stage microscopy}

The results of investigations into thermal expansion of the A series samples from the upper horizon of the Dylagówka deposit (the natural sample and its modifications) under a hot-stage microscope (Fig. 5) are characterized by the ratio of the cross-sectional areas: that of the sample after thermal treatment $S_{t}$ and that of the starting (natural) sample $S_{0}$. The highest increase in the cross-sectional area is shown by the acid-activated sample A2, which thermally expands at above $250 \%$. It is a result of a partial decomposition of smectite, formation of the protonated silica gel, andnext-formation of an alkali melt containing alkalis $\left(\mathrm{K}_{2} \mathrm{O}\right.$ and $\mathrm{Na}_{2} \mathrm{O}$ ). At the temperatures between 1200 and $1300{ }^{\circ} \mathrm{C}$, a fast increase in the sample volume was noted due to the capability of a highly viscous melt to retain gases in the expanding product. Its expansion proceeds until the outer, vitreous cover begins to crack, which is marked as a stepwise change in the shape of the curves and a rapid decrease in expansion. As a result, gases are released from the product, for instance, the oxygen evolving from the reduction of iron(III) oxide in the reaction $\mathrm{Fe}_{2} \mathrm{O}_{3} \rightarrow 2 \mathrm{FeO}+1 / 2 \mathrm{O}_{2}$.

Some lower values of thermal expansion, around $200 \%$, are shown by samples A and A1, i.e. the natural one and the sodium-modified one, respectively. Comparing the two, the sodium-modified sample increases its volume at lower temperatures (with a maximum expansion at around $1250{ }^{\circ} \mathrm{C}$ ) because of a significant content of a fluxing agent in the form of a $5 \%$ by mass addition of $\mathrm{Na}_{2} \mathrm{CO}_{3}$. Nevertheless, the melt originating shows a lower viscosity, and the expansion process is terminated at the temperatures lower than those of the natural sample. The samples fired at
$560{ }^{\circ} \mathrm{C}$ have slightly lower expansion values (around $175 \%$ ), and the expansion ranges are comparable with those of the samples not modified thermally. It may be a

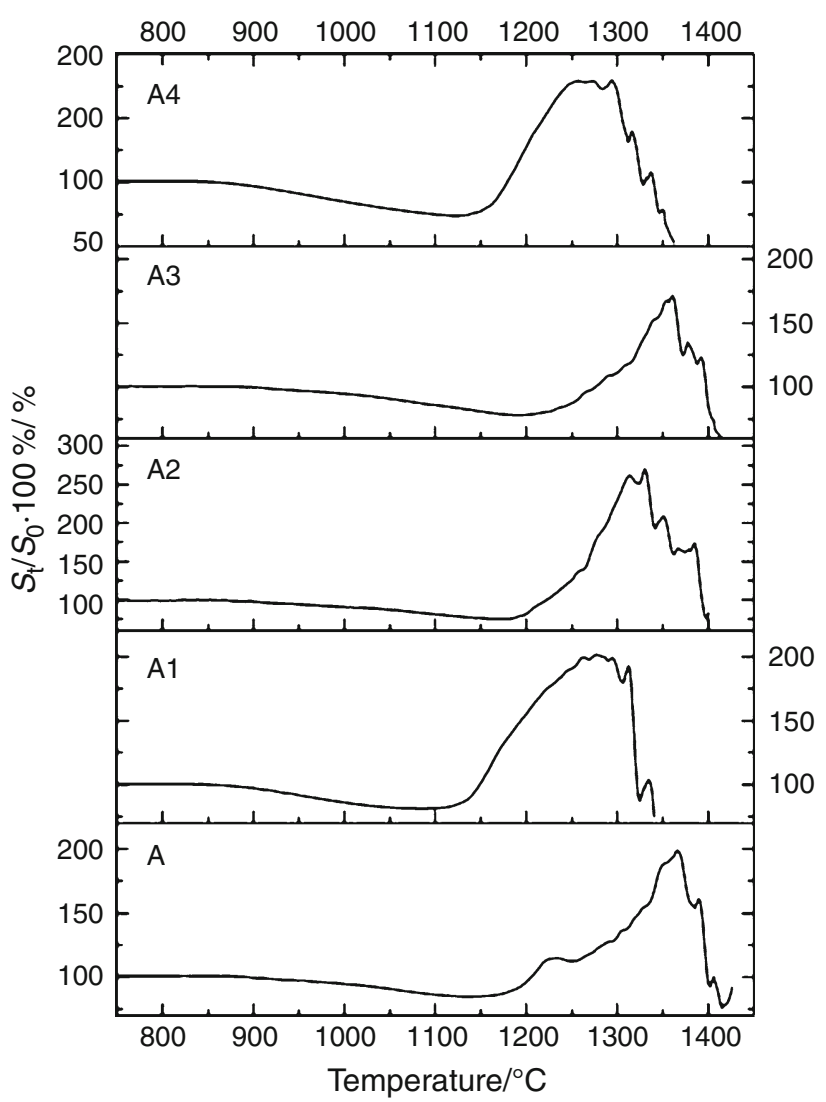

Fig. 5 Expansion values of the claystone from the upper horizon of the Dylągówka deposit (natural sample $A$ and the products of its modification: samples $A 1-A 4)$ in the function of the temperature of sample processing: $A 1$ - sample activated with $5 \%$ (by mass) of $\mathrm{Na}_{2} \mathrm{CO}_{3}, A 2$-sample activated with $10 \%$ solution of $\mathrm{H}_{2} \mathrm{SO}_{4}, A 3-$ sample fired at $560{ }^{\circ} \mathrm{C}, A 4-$ sample activated with $5 \%$ (by mass) of $\mathrm{Na}_{2} \mathrm{CO}_{3}$ and then fired at $560{ }^{\circ} \mathrm{C}$

Table 1 Selected parameters of the thermal expansion process of the samples (determined on the basis of HSM microscopy)

\begin{tabular}{|c|c|c|c|c|}
\hline $\begin{array}{l}\text { Sample } \\
\text { symbol }^{\mathrm{a}}\end{array}$ & $\begin{array}{l}\text { Temperature of the beginning } \\
\text { of expansion } t_{\mathrm{p}} /{ }^{\circ} \mathrm{C}\end{array}$ & $\begin{array}{l}\text { Temperature of the maximum } \\
\text { expansion } t_{\mathrm{k}}{ }^{\circ} \mathrm{C}\end{array}$ & $\begin{array}{l}\text { Temperature range } \\
\text { of firing } I /{ }^{\circ} \mathrm{C}\end{array}$ & $\begin{array}{l}\text { Expansion }\left(S_{\mathrm{t}} / S_{0} \cdot 100 \%\right) \\
\text { of the samples at the } t_{\mathrm{k}} \\
\text { temperature } / \%\end{array}$ \\
\hline A & 1207 & 1355 & 148 & 191 \\
\hline A1 & 1150 & 1248 & 98 & 187 \\
\hline $\mathrm{A} 2$ & 1222 & 1308 & 86 & 258 \\
\hline A3 & 1275 & 1340 & 65 & 167 \\
\hline A4 & 1179 & 1245 & 66 & 178 \\
\hline B & 1244 & 1330 & 86 & 156 \\
\hline B1 & 1193 & 1255 & 62 & 157 \\
\hline B2 & 1239 & 1312 & 73 & 268 \\
\hline $\mathrm{C}$ & 1211 & 1266 & 55 & 151 \\
\hline $\mathrm{C} 1$ & 1177 & 1236 & 59 & 208 \\
\hline $\mathrm{C} 2$ & 1235 & 1262 & 27 & 167 \\
\hline
\end{tabular}

a Sample symbols (A1-C2) are explained in the text, e.g. in the descriptions of Figs. 4-6 
result of a lower amount of gases generated and released during a burn-down of organic substances and dehydroxylation of clay minerals.

Detailed characteristics of the thermal expansion are presented (Table 1) as the following parameters:

- The temperature of the beginning of expansion $t_{\mathrm{p}}$, assumed as the temperature at which the cross-sectional area of the sample after its softening and a further volume increase reaches back the volume of the starting sample, i.e. the cross section of the initial sample;

- The temperature of the maximum expansion $t_{\mathrm{k}}$, at which the sample size is the biggest and, at the same time, the sample is the highest;

- The temperature range of firing $I$, determined as the difference between the $t_{\mathrm{k}}$ and $t_{\mathrm{p}}$ temperatures;

- The expansion of the sample, expressed as $S_{\mathrm{t}} / S_{0}$. $100 \%$, where $S_{\mathrm{t}}$ is the sample cross-sectional area at the temperature of measurements $t_{\mathrm{k}}$, and $S_{0}$ the crosssectional area of the natural sample.

The samples (Table 1) reveal a wide temperature range of firing $I$ between 65 and $148{ }^{\circ} \mathrm{C}$ because of a significant amount of opal. Previous investigations [16] proved that the value of this parameter is significantly lower in the mineral raw materials not containing opal. Sample A shows a particularly wide range of firing temperatures $I\left(148{ }^{\circ} \mathrm{C}\right)$ used to obtain an expanded product. Looking at the economics of the LECA production, a significant lowering of the firing temperatures must be considered when an untreated mineral material is modified with $\mathrm{Na}_{2} \mathrm{CO}_{3}$.

The temperature-induced changes in the cross-sectional areas of the claystone samples, both natural and modified, localized in the middle and lower horizons of the Dylagówka deposit are presented in Fig. 6, while the process parameters in Table 1. The data on thermal expansion of the fired claystones from the middle and lower horizons do not differ from those discussed for samples A3 and A4 and for this reason have not been shown here. In the case of the samples from the middle horizon (symbols B, B1, and B2), the temperature range of firing of the sodium-activated sample (B1) shifted towards lower temperatures (the beginning of expansion dropped from 1244 to $1193{ }^{\circ} \mathrm{C}$ ) and the expansion of the $\mathrm{H}_{2} \mathrm{SO}_{4}$-modified samples (B2) considerably improved (from 156 to $268 \%$ ). In the claystone samples from the lower horizon $(\mathrm{C}, \mathrm{C} 1$, and $\mathrm{C} 2)$, the

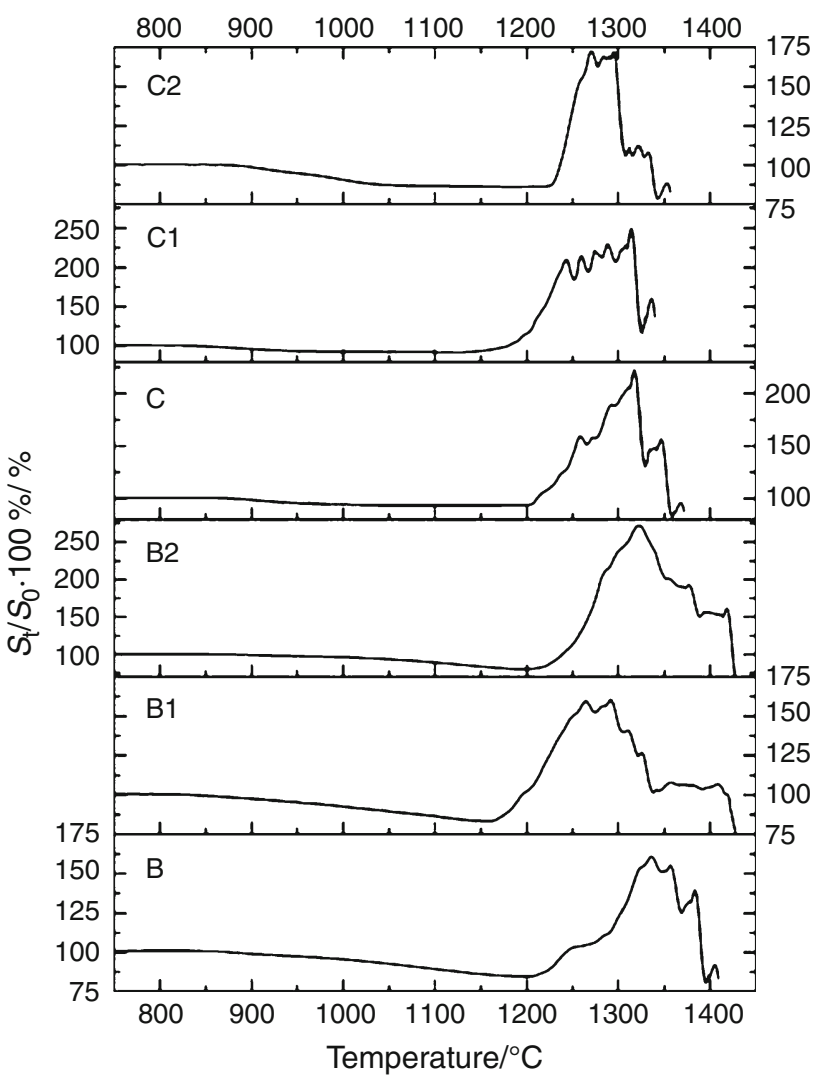

Fig. 6 Expansion of the claystones from Dylagówka, representing the middle (sample $B$ ) and lower (sample $C$ ) horizons of the deposit and of the products of their modification depending on the temperature of thermal processing: $B 1, C 1$-samples activated with $5 \%$ (by mass) of $\mathrm{Na}_{2} \mathrm{CO}_{3} ; B 2, C 2$ - samples activated with $10 \%$ solution of $10 \% \mathrm{H}_{2} \mathrm{SO}_{4}$

effects of modifications were reversed. In the sodium-activated sample $(\mathrm{C} 1)$, the expansion increased from 151 to $208 \%$. However, the acid activation (sample C2) increased the expansion at the $t_{\mathrm{k}}$ temperature only slightly, from 151 to $167 \%$.

A reason of these phenomena is caused by differences of the mineral and chemical composition (Table 2) of the samples from the lower horizons (sample $\mathrm{C}$ ) of the deposit in comparison with the samples A and B from the upper and middle horizons, respectively. Acid activation (sample C2) has not brought about desired effects because of a considerable amount of calcite in the natural rock (Fig. 1). On one hand, the strong sulphuric acid was consumed in

Table 2 Main chemical components (mass\%) of the natural claystones from Dylągówka, representing the upper (1), middle (2), and lower (3) horizons of the deposit

\begin{tabular}{lcccccccccrrr}
\hline Sample symbol & $\mathrm{SiO}_{2}$ & $\mathrm{Al}_{2} \mathrm{O}_{3}$ & $\mathrm{Fe}_{2} \mathrm{O}_{3}$ & $\mathrm{TiO}_{2}$ & $\mathrm{CaO}$ & $\mathrm{MgO}$ & $\mathrm{MnO}$ & $\mathrm{Na}_{2} \mathrm{O}$ & $\mathrm{K}_{2} \mathrm{O}$ & $\mathrm{P}_{2} \mathrm{O}_{5}$ & $\mathrm{LOI}$ & $\mathrm{Total}$ \\
\hline A & 58.08 & 15.45 & 7.02 & 0.65 & 0.90 & 1.66 & 0.09 & 0.37 & 2.57 & 0.09 & 11.02 & 97.91 \\
$\mathrm{~B}$ & 66.71 & 12.21 & 4.82 & 0.52 & 0.86 & 2.05 & 0.10 & 0.28 & 2.11 & 0.09 & 10.67 & 100.40 \\
$\mathrm{C}$ & 58.26 & 12.64 & 4.11 & 0.71 & 5.02 & 1.29 & 0.01 & 0.46 & 0.67 & 0.04 & 16.68 & 99.88 \\
\hline
\end{tabular}


the reaction with this mineral (decomposition of the carbonate) as it was proved by carbon dioxide evolving in the process of acid activation. On the other, a low alkali content $\left(\mathrm{Na}_{2} \mathrm{O}\right.$ and $\left.\mathrm{K}_{2} \mathrm{O}\right)$ was insufficient to generate at relatively lower temperatures (ca. $1250{ }^{\circ} \mathrm{C}$ ) a liquid phase capable of dissolving silica. This results in a low firing interval, ca. $27^{\circ} \mathrm{C}$, of sample $\mathrm{C} 2$ (Table 1). Therefore, it was only spiking the natural clay rock from the lower horizon with $\mathrm{Na}_{2} \mathrm{CO}_{3}$ (sample $\mathrm{C} 1$ ) that resulted in a significant expansion of this raw material.

\section{Conclusions}

The claystones with a considerable amount of smectite, in which also occur zeolites and some amounts of other clay minerals (illite, kaolinite) and of non-clay components (haematite, opal, quartz, calcite), have revealed their thermal expansion capability at the temperatures exceeding $1000{ }^{\circ} \mathrm{C}$. On the basis of thermal analyses and X-ray diffraction, it has been possible to determine the effects of sodium additives, acid, and thermal modifications on the properties of these clay commodities and described the character of structural changes in smectite. The DTA and TG analyses have shown a considerable diversification of thermal effects generated by smectite. In the sodium-modified samples, the effect of dehydroxylation of smectite (the main mineral component) was enhanced and shifted in the DTG analyses towards the temperatures higher in comparison with those of the natural rock samples. In the case of clay samples modified with sulphuric acid, the maxima at 800 and $900{ }^{\circ} \mathrm{C}$ have been recorded as proofs of the $\mathrm{SO}_{2}$ emissions (from decomposing secondary sulphate phases).

The effects of thermal expansion have been recorded using the method of high-temperature microscopy. It has been determined that an addition of 5 mass $\%$ of sodium carbonate considerably decreases the temperature of expansion. In turn, the claystones with low contents of $\mathrm{CaO}$ have revealed higher expansion after being treated with sulphuric acid. The presence of a protonated silica gel, a final product of smectite alterations in the process the sodium activation of a clay material containing alkalis, results in the formation of a melt of high viscosity. A cover formed in such a case on the surface of resultant product prevents the escape of gases at relatively high temperatures and favours manufacturing of the expanded product. The acid treatment has been found inefficient in the case of clay rocks containing higher amounts of calcite; such a procedure does not improve expanding capabilities. The reaction of this mineral with a strong acid (sulphuric acid was used by the authors) resulting in the evolution of carbon dioxide and the formation of calcium sulphate-and small content of alkali have been established as a major reason of this obstacle.
Open Access This article is distributed under the terms of the Creative Commons Attribution 4.0 International License (http://creati vecommons.org/licenses/by/4.0/), which permits unrestricted use, distribution, and reproduction in any medium, provided you give appropriate credit to the original author(s) and the source, provide a link to the Creative Commons license, and indicate if changes were made.

\section{References}

1. Murray HH. Occurrences, processing and application of kaolins, bentonites, palygorskite-sepiolite, and common clays. Applied clay mineralogy. Amsterdam: Elsevier; 2007.

2. Grim RE. Clay mineralogy. New York: McGraw-Hill Book Company, Inc.; 1953.

3. Madejová J, Bujdák J, Janek M, Komadel P. Comparative FT-IR study of structural modifications during acid treatment of dioctahedral smectites and hectorite. Spectrochim Acta A. 1998;54:1397-406.

4. Komadel P. Chemically modified smectites. Clay Miner. 2003;38:127-38.

5. Bahranowski K, Gaweł A, Komorek J. Acidity of acid-activated $\{\mathrm{Al}\}-$ and $\{\mathrm{Zr}\}$ - pillared clays: ante-pillaring versus post-pillaring treatment. Miner Polon. 2001;32(2):57-65.

6. Pentrák M, Czímerová A, Madejová J, Komadel P. Changes in layer charge of clay minerals upon acid treatment as obtained from their interactions with methylene blue. Appl Clay Sci. 2012;55:100-7.

7. Frost RL, Ruan H, Kloprogge JT, Gates WP. Dehydration and dehydroxylation of nontronites and ferruginous smectite. Thermochim Acta. 2000;346:63-72.

8. Wacławska I. Dehydration and dehydroxylation of smectites. I. Dehydration and dehydroxylation kinetics. Miner Polon. 1984;15(1-2):91-108.

9. Ayari F, Srasra E, Trabelsi-Ayadi M. Effect of exchangeable cations on the physicochemical properties of smectite. Surf Eng Appl Electrochem. 2007;43(5):369-78.

10. Bradley WF, Grim RE. High temperature thermal effects of clay and related materials. Am Miner. 1951;36:182-201.

11. He Ch, Makovicky E, Osbæck B. Thermal stability and pozzolanic activity of raw and calcined mixed-layer mica/smectite. Appl Clay Sci. 2000;17:141-61.

12. Ardakani A, Yazdani M. The relation between particle density and static moduli of lightweight expanded clay aggregates. Appl Clay Sci. 2014;93-94:28-34.

13. Ozguven A, Gunduz L. Examination of effective parameters for the production of expanded clay aggregate. Cem Concr Comp. 2012;34:781-7.

14. Bender W, Händle F. Brick and tile making. Wiesbaden und Berlin: Bauverlag GmbH; 1982.

15. O’Driscoll M. Clays under fire. Ind Miner. 2000;391(4):29-39.

16. Panna W, Wyszomirski P, Gasek K, Dudek R, Łabuz A. Hot stage microscopy in determining the suitability of selected clay rocks from south-eastern Poland to manufacture lightweight aggregates. Cement Wapno Beton. 2015;20(2):79-87.

17. Panna W, Wyszomirski P, Myszka R. Characteristics of the clayey-siliceous rock from the Dylągówka-Zapady deposit (Polish flysch Carpathians) as a mineral raw material. Gosp Sur Min. 2014;30(2):87-105 (in Polish).

18. Wyrwicki R. Derivatographic analysis of clay rocks. Warszawa: Warsaw University; 1988 (in Polish).

19. Bray HJ, Redfern T. Influence of counterion species on the dehydroxylation of $\mathrm{Ca}^{2+}, \mathrm{Mg}^{2+}, \mathrm{Na}^{+}$- and $\mathrm{K}^{+}$-exchanged Wyoming montmorillonite. Miner Mag. 2000;64(2):337-46.

20. Christidis GE, Scott PW, Dunham AC. Acid activation and bleaching capacity of bentonites from the islands of Milos and Chios, Aegean. Greece App Clay Sci. 1997;12:329-47. 